УДК 347.2

\title{
СТАНОВЛЕНИЕ И РАЗВИТИЕ ИНСТИТУТА ЗАЩИТЫ ИМУЩЕСТВЕННЫХ ПРАВ СУПРУГОВ
}

\author{
Сербин Михаил Викторович \\ заведующий кафедрой государственного права, \\ кандидат юридических наук, доцент, \\ Вице-президент Молодежного союза юристов РФ \\ Сербина Лейла Арифовна \\ старший преподаватель кафедры \\ гражданского права \\ ФГАОУ ВО «Санкт-Петербургский государственный \\ университет аэрокосмического приборостроения»
}

Аннотация: В статье проанализировано становление и развитие института защиты имущественных прав супругов. Институт защиты имущественных прав супругов, как и любой другой институт имеет свою историю, свой путь становления и развития, благодаря которым можно узнать о его особенностях, сущности и значении в современном мире. Данный институт рассматривается с того же времени, с которого и существуют понятия семья и брак.

Ключевые слова: Защита, имущество супругов, режим, собственность.

\section{FORMATION AND DEVELOPMENT OF THE INSTITUTION OF PROTECTION OF PROPERTY RIGHTS OF SPOUSES}

\section{Serbin Mikhail Viktorovich Serbina Leila Arifovna}

\begin{abstract}
The article analyzes the formation and development of the institution of protection of property rights of spouses. The Institute for the Protection of Property Rights of spouses, like any other institution, has its own history, its own path of formation and development, thanks to which you can learn
\end{abstract}




\section{ЭКОНОМИКА, УПРАВЛЕНИЕ, ПРАВО: АКТУАЛЬНЫЕ ВОПРОСЫ И ВЕКТОРЫ РАЗВИТИЯ}

about its features, essence and significance in the modern world. This institution is considered from the same time as the concepts of family and marriage exist.

Key words: Protection, marital property, regime, property.

В настоящее время брак является привычным и известным юридическим фактом для большинства людей. Понятие брака берет свое начало из Древнего Рима, где данное понятие трактовали немного иначе, в отличие от современных правовых тенденций и законодательства не только РФ, но и большинства других зарубежных стран. Брак по своей правовой природе представляет собой одну из разновидностей договоров. По мнению известного римского ученого Модестина, брак представлял собой некий союз, заключенный между мужчиной и женщиной на всю жизнь и характеризующийся как некое единство человеческих и божественных начал $[2, \mathrm{c} .158]$.

Также необходимо напомнить, что изначально в Древнем Риме брак являлся брачным союзом, где вся полнота власти была в руках у мужчины над женщиной, что говорит о господстве патриархального характера. Так, мужу предоставляли некоторые права в отношении своей жены, а жена несла исключительно обязанности имущественного характера. Однако, можно заметить, что такие принципы являются неприемлемыми на сегодняшний момент, поскольку нарушают большое количество норм семейного, гражданского и даже конституционного законодательства.

В браке «с властью мужа» предполагалось, что после его заключения, жена утрачивала какую-либо юридическую связь со своей прежней семьей и становилась подчиненной воли и власти мужа. Все принадлежащее супруге имущество переходило к еe супругу в момент заключения брака и становилось его собственностью, которым он мог распоряжаться единолично. Данное право не могло быть никем ограничено, в том числе и родственниками супруги. Также они не могли вмешиваться в распоряжение этим имуществом. Все имущество, которое жена приобретала во время брака (например, купленное ею на рынке, подарки её отца и братьев), тоже принадлежало ее супругу. Также супруг, как абсолютный собственник, имел полное право виндикации на любое имущество, которое принадлежало его супруге, даже в отношении ее прежней семьи. Однако, в случае смерти супруга, жена приобретала право на наследование в качестве агнатической родственницы. 


\section{ЭКОНОМИКА, УПРАВЛЕНИЕ, ПРАВО: АКТУАЛЬНЫЕ ВОПРОСЫ И ВЕКТОРЫ РАЗВИТИЯ}

Брак «без власти мужа» напротив, не изменял каким-либо образом юридического и имущественного положения жены. Она оставалась подчиненной отцовской власти и после вступления в брак. В случае, если она была до вступления в брак правоспособным лицом, то и после вступления в брак она оставалась лицом своего права. В данном случае имущество, приобретенное ею до брака, являлось ее личной собственностью. А все имущество, приобретенное ею в браке, принадлежало ей самой. Таким образом, в браке «без власти мужа» действовал принцип раздельности имущества супругов. Издержки же совместной супружеской жизни ложились полностью на мужа. Однако, он приобретал право распоряжаться всем доходом, который приносило имущество его жены.

В этой форме брачных отношений муж не имел права без разрешения своей супруги или ее прежнего домовладыки отчуждать принадлежащее ей имущество. Более того, родственники жены могли предъявить ее супругу иск и требования о восстановлении всего ее личного имущества. А супруга, в свою очередь, имела право вступить в имущественную сделку. Однако в данной ситуации запрещалось дарение. Муж, в свою очередь, мог распоряжаться личным имуществом своей супруги только по договору поручения. Раздельной также являлась и имущественная ответственность супругов. Если происходил имущественный спор, то действовала презумпция: «Все имущество принадлежит мужу, пока жена не докажет обратное».

Но, со временем, такая полная имущественная разобщенность супругов в данной форме брака начала смягчаться не только в их личных отношениях, но и в имущественных. Было признано, что супруги не вправе предъявлять друг другу инфамирующие иски (то есть, иски, предполагающие недобросовестность лица), так как в случаях имущественной ответственности одного супруга перед другим он пользовался правом отвечать только в пределах, имеющихся у него средств. Преторы стали давать мужьям интердикты для истребования своих жен. При этом преторы отказывали отцу, если тот пытался истребовать свою дочь, находящуюся в браке «без власти мужа».

Однако уже в римском праве было отмечено одно из первых упоминаний о брачном договоре, который и являлся прообразом современного настоящего брачного договора. «Мужчина и женщина прежде, чем создать семью, оформляли соглашение, где определяли свои 


\section{ЭКОНОМИКА, УПРАВЛЕНИЕ, ПРАВО: АКТУАЛЬНЫЕ ВОПРОСЫ И ВЕКТОРЫ РАЗВИТИЯ}

имущественные отношения, в том числе и такие вопросы, как наследования в будущем совместно нажитого имущества» [1, с.75]. Действующее законодательство, как известно, позаимствовало концепцию и специфику института брачного договора как раз-таки из частного права Рима. Однако необходимо упомянуть, что брачные договоры в Древнем Риме характеризовались рациональностью и осмысленностью. В то время брачные контракты представляли собой соглашения между супругами, которые устанавливали объем и качество приданого и предбрачного дара.

С течением времени и распространением христианства в Европе, эпоха римской империи стала постепенно сменяться эпохой феодализма. Важной чертой развития государств Западной Европы периода феодальной раздробленности было отсутствие единого права для всей страны. Однако, многие правовые основы существовали не только в национальных, но и в общеевропейских масштабах. Этот факт можно объяснить единством социально-экономических процессов. В это же время началось деление западноевропейского права на англосаксонскую и континентальную ветви права, основой которого стало римское право. Однако, большое влияние на формирование обеих правовых систем сыграла церковь, поскольку она являлась в то время мощной экономической, политической и культурной организацией и, самое главное, носителем общеевропейской идеологии виде христианской религии. Догматы церкви стали аксиомами в повседневной в жизни, а библейские тексты приобрели силу законов.

Так же, как и в раннем римском праве, семейные отношения были построены на полной власти мужа или отца женщины и полной имущественной неправоспособности женщины. Хотя в разных областях одного государства такая власть имела различный характер. Например, в северной части Франции взаимоотношения между супругами были мягче и свободнее и строились на общности имущества и свободе решать свои имущественные отношения по обоюдному согласию. Однако на юге Франции общности имущества супругов не существовало. Муж получал приданое, которым он управлял в течение брака и которое возвращалось его супруге в случае смерти ее мужа. Все имущественные сделки, совершенные женой без согласия ее мужа, признавались ничтожными. Все семейные отношения регулировались каноническими нормами, основанными на церковных вероучениях католической церкви, поскольку церковь была не только 


\section{ЭКОНОМИКА, УПРАВЛЕНИЕ, ПРАВО: АКТУАЛЬНЫЕ ВОПРОСЫ И ВЕКТОРЫ РАЗВИТИЯ}

носителем феодальной идеологии, но и жестоким карающим органом, каравшим любого, отступившего от ее требований.

В Англии, так же как и в Германии, семья носила патриархальный характер. Женщины имели в семье некоторую свободу распоряжением имуществом, однако они по-прежнему находились под властью своих мужей. Причем в высших слоях общества жена полностью находилась под властью своего мужа. Она имела право на наследование его имущества, но не имела при этом права распоряжения этим имуществом - оно передавалось старшему из сыновей при достижении им 14-летнего возраста. То есть, существовало правило сохранения имущества. Женщины низших сословий пользовались относительной свободой. Они могли распоряжаться своим имуществом, заключать сделки и заниматься торговлей.

Так, в Германии в 7-9 вв. согласно Германскому Гражданскому Уложению, муж являлся главой семьи, в то время как все имущественные права, свободы и обязанности супругов определялись путем заключения брачного договора, который, как правило, устанавливал режим раздельной собственности.

Также о концепциях, похожих на брачный договор, говорил и Великий князь литовский Александр Каземирович, определив, что супруги приносят свое приданное и иное имущество в семью, которое переходит их детям по наследству. Супруг в целях сохранения целостности приданного его супруги платил залог н часть своего имущества. Это называлось веновая запись, что и являлось прообразом современного брачного договора. Больше внимания стало уделяться вопросу регулирования имущественных прав супругов с появлением Статута 1588 года, который устанавливал положения, касающиеся обеспечения материального содержания супруги.

Во Франции подобные законы были приняты несколько позже. Французское право традиционно считалось наиболее консервативным относительно равноправия женщин. Так, например, в Кодекса Наполеона 1804 устанавливалось равенство прав и свобод мужа и жены, но муж по-прежнему продолжал занимать главенствующее положение в семье. в соответствии с Кодексом Наполеона муж без согласия жены был вправе распоряжаться совместно нажитым имуществом. Статья 217 Кодекса Наполеона устанавливает имущественные ограничения супруги: «Жена, даже при отсутствии общности имущества супругов или при раздельности их 


\section{ЭКОНОМИКА, УПРАВЛЕНИЕ, ПРАВО:

имущества, не вправе отчуждать, закладывать, приобретать по возмездному и безвозмездному основанию, без участия мужа в сделке или без его письменного разрешения». Но начиная с конца XVIII - начала XIX века закон предоставил женщинам право самим распоряжаться своими сбережениями, делать вклады в банках. В начале XX века закон предоставляет женщинам право распоряжаться своим заработком, право без разрешения мужа выступать в суде, право приобретать и отчуждать имущество.

Германское уложение не применяло легальной власти мужа над женой. Но при этом и не признавало равноправия супругов в браке. Также Германское уложение устанавливало режим общности на все общее имущество супругов, приобретенное в период брака. Более того муж имел право пользоваться и управлять данным имуществом без согласия жены. В данном случае согласно параграфу 1363 Германского гражданского уложения все имущество супруги, приобретенное до вступления в брак, являлось ее личной собственность, с правом супруга владеть и распоряжаться им: «Силою заключения брака имущество жены подчиняется управлению и пользованию мужа (внесенное имущество). К внесенному имуществу относится также имущество, которое жена приобретает во время брака». Также помимо данного режима Германское гражданское уложение также установило и режим отдельного имущества супруги, владеть которым муж не имел право. Такое имущество включает личные вещи жены и имущество, которое она получила в качестве дара или наследственности, а также имущество, приобретенное собственным трудом супруги. Таким образом, можно утверждать, что несмотря на то, что к концу XIX века женщины не овладели таким же статусом, как и мужчины, однако уже в это время появляться более благоприятная система для жен в отношении имущественных прав.

К началу XVIII века начинает складываться принцип раздельности имущества супругов. Женщины получили право иметь в собственности недвижимое имущество (вотчины), которые они получали во время брака в качестве дара или наследуемого имущества. Также за женщинами закреплялось исключительное право собственности на ее приданое. Однако, входить в обязательственные отношения супруга могла, только «если она сама от своего лица не производит торговли». В конце XVIII века Сенат разрешает женщинам распоряжаться своим имуществом без согласия на то их мужей. 


\section{ЭКОНОМИКА, УПРАВЛЕНИЕ, ПРАВО: АКТУАЛЬНЫЕ ВОПРОСЫ И ВЕКТОРЫ РАЗВИТИЯ}

Так, наконец, в 1832 году Свод законов Российской Империи установил режим раздельного имущества супругов. Несмотря на то, что жена все же оставалась под властью мужа, брак не оказывал больше влияние на имущественные отношения супругов. Так, в соответствии со статьей 109 Свода законов Российской Империи браком не составляется общего владения в имуществе супругов; каждый из супругов может иметь и вновь приобретать отдельную свою собственность.

Более того, теперь к отдельному имуществу супруги относились: приданное и имущество супруги, которое она получила в качестве дара или наследственности или приобрела во время брака по договору купли-продажи. Таким образом, необходимо сказать, что супруги считались равными сторонами гражданского оборота. А власть мужа заключалась в выборе места жительства, а также в обязанности защищать всю свою семью [3, с.86].

Можно сделать вывод, что с течением времени равноправие супругов выходит на другой уровень, где муж уже не имеет власти над имуществом супруги, но в то же время имеет власть на личные неимущественные притязания к своей супруге.

В начале XX века в России сложился уникальный, не имеющий аналогов, правовой режим, регулировавший имущественные отношения супругов. Этот режим предполагал, с одной стороны, полную подчиненность жены своему мужу, а с другой - ее полную имущественную независимость. В странах континентальной Европы, в то же время, существовал режим универсальной общности движимого и приобретенного имущества супругов.

Можно заметить, что Россия и большинство зарубежных стран в вопросе реализации защиты имущественных прав супругов придерживались одного и того же принципа, это выражается в одинаковом или похожем пути становления данного института. Проанализировав историю его развития, можно проследить схожести в регулировании имущественных прав супругов согласно религиозно-правовым принципам. Так, например, многие страны Европы находились под влиянием римской католической церкви, в то время как в России русская православная церковь оказывала огромное влияние на регулирование данных вопросов.

Также необходимо отметить то, что с ранних времен люди защищали свои имущественные права и свободы посредством заключения договоров, хотя это не называлось «брачным договором», но имело очень похожее 
содержание и значение. Однако так называемые брачные договоры того времени не характеризовались своей демократичностью, поскольку данный договор был принудительным, а также зачастую решение о заключении брака принимали не сами будущие супруги, а их родители. Что категорически противоречит современному действующему принципу добровольности брачного союза.

Подводя итог, следует сказать, что на протяжении всего времени вопросы, возникающие в отношении определения и защиты имущественных прав супругов, представляются очень спорными и неоднозначными. Необходимо отметить, что долгое время все проблемы, касающиеся бракоразводного процесса и, как следствие, раздела совместного имущества супругов, решались в силу определенных оснований, а именно согласно православной идеологии.

\section{Список литературы}

1. Гаспарян А.С., Атрохова Е.С. Брачный контракт. Гарантия семейного счастья. Ростов н/Д: Феникс, 2004. - С. 75

2. Силакова О.Н, Лахта В.А. Особенности брачных отношений в праве Древнего Рима // Журнал «Архивариус». 2016.С.158

3. Чужинова Ю.А. Особенности правового регулирования законного режима имущества супругов в Российской Федерации // Вестник Московского университета МВД России. 2015. № 28. С.86

(C) М.В. Сербин, Л.А. Сербина, 2021 